\title{
PENILAIAN RISIKO KELUARGA TERKAIT COVID-19 MENGGUNAKAN APLIKASI ASSESMENT KELUARGA INARISK
}

\author{
Amila $^{1}$, Johansen Hutajulu ${ }^{2}$, Evarina Sembiring ${ }^{3}$, Jon Carlos Tobing ${ }^{4}$ \\ 1,2,4 Program Studi Ners, Fakultas Farmasi dan Ilmu Kesehatan, Universitas Sari Mutiara Indonesia \\ ${ }^{3}$ Program Studi Kesehatan Masyarakat, Fakultas Farmasi dan Ilmu Kesehatan, Universitas Sari Mutiara \\ Indonesia \\ Email: ${ }^{1}$ mila_difa@yahoo.co.id, ${ }^{2 j o j o 3 b o y @ y a h o o . c o m, ~}{ }^{3}$ evarrinasembiring@gmail.com
}

\begin{abstract}
ABSTRAK
Saat ini dunia sedang dilanda pandemi Covid-19 yaitu suatu penyakit menular yang disebabkan oleh virus corona baru. Huta Marubun I adalah wilayah yang memiliki resiko terpapar Covid-19. Tujuan penelitian ini untuk mengetahui gambaran penilaian resiko keluarga terkait Covid-19 menggunakan aplikasi asessment Keluarga Inarisk di Huta Marubun I Nagori Marubun Jaya. Tools penilaian risiko ini dikelola oleh Gugus Tugas Percepatan Penanganan Covid-19 sebagai bentuk informasi resmi ke masyarakat terkait dengan pandemi COVID-19. Jenis penelitian ini adalah deskriptif. Populasi penelitian adalah 130 Kepala Keluarga Huta Marubun I dan sampel penelitian berjumlah 33 kepala Keluarga yang diambil menggunakan teknik acak. Penilaian resiko keluarga terdiri dari Resiko Rendah jika skor jawaban responden 35-42, Resiko Sedang jika skor jawaban responden 28-34 dan Resiko Tinggi jika skor jawaban responden 21-27 digunakan. Di Huta Marubun I terdapat 14 Kepala keluarga memiliki resiko rendah, 19 kepala keluarga resiko sedang dan tidak ada satupun keluarga memiliki resiko tinggi. Keluarga tetap juga memiliki resiko terpapar Covid-19, oleh karena itu disarankan untuk tetap menjalankan protokol kesehatan, sehingga dapat mencegah Covid-19. Rekomendasi yang diberikan oleh aplikasi inaRisk untuk Keluarga adalah sebaiknya tinggal dirumah, menggunakan masker pada saat berkumpul dengan orang lain dan menerapkan pola hidup bersih dan sehat.
\end{abstract}

Kata Kunci: Corona virus, InaRISK, Penilaian Resiko Keluarga.

\section{ABSTRACT}

Currently the world is being hit by the Covid-19 pandemic, which is an infectious disease caused by the new corona virus. Huta Marubun I is an area that is at risk of being exposed to Covid-19. The purpose of this study was to describe the risk assessment of families affected by Covid-19 using the Inarisk Family assessment application at Huta Marubun I Nagori Marubun Jaya. This risk assessment tool is managed by the Task of Covid-19 Handling as a form of official information to the public regarding the COVID-19 pandemic. This type of research is descriptive quantitative. The population was 130 heads of families of Huta Marubun I and the sample in this study was 33 heads of families who were taken using simple random sampling technique. The family risk assessment consists of Low risk if the respondent's answer score is 35-42, moderate risk if the respondent's answer score is 28-34 and high risk if the respondent's answer score is 21-27 is used. In Huta Marubun I there are 14 heads of low risk families, 19 heads of medium risk families and none of the families are at high risk. Families still have the risk of being exposed to Covid-19, therefore it is advisable to stick to health protocols to break the chain of spread of Covid 19. The recommendations given by the inaRisk application for families are that you should stay at home, use a mask when gathering with other people and apply a pattern. clean and healthy life.

Keywords: Corona virus, InaRISK, Family Risk Assessment.

\section{PENDAHULUAN}

Saat ini seluruh dunia sedang menghadapi pandemi Covid 19 atau virus corona. Indonesia menjadi salah satu negara yang merasakan pandemi ini. Pada tanggal 30 Januari 2020, Organisasi Kesehatan Dunia (WHO) menyatakan 2019-nCOV menjadi Masalah Kesehatan Umum Emergensi Tingkat Internasional karena peningkatan signifikan kasus baru yang dikonfirmasi diberbagai Negara (Kementerian Kesehatan Republik Indonesia, 2020).

Banyaknya kasus baru yang terus berlanjut setiap hari, yang tersebar di 34 Provinsi dan hampir tersebar di seluruh kabupaten di Indonesia, pemerintah perlu mengambil tindakan yang berdampak dalam penurunan kasus Covid-19 seperti kebijakan pemerintah untuk membentuk satuan tugas Covid-19, instruksi bagaimana menggunakan 
masker, pembatasan fisik dan sosial, penelitian dan inovasi untuk melawan pandemi Covid-19.

Pandemi Covid-19 tidak hanya berdampak terhadap kesehatan saja namun terhadap semua sektor. Dampak pandemi ini telah melumpuhkan sebagian besar sektor perekonomian utamanya di negara-negara berkembang. Kebijakan pemerintah sebagai upaya pencegahan penularan dan penyebaran virus Covid-19 telah berdampak secara ekonomi bagi masyarakat (Berawi, 2020; Irawan et al., 2020).

Penerapan program Pembatasan Sosial Berskala Besar (PSBB) dan lock down menyebabkan dampak ekonomi yang luar biasa bagi sebagian besar negara-negara berkembang. Hal tersebut mengakibatkan krisis ekonomi dan tingginya tingkat Pemutusan Hubungan Kerja (PHK) di sektor industri karena perusahaan tersebut tidak mampu menggaji karyawannya yang dirumahkan selama penerapan PSBB.

Berbagai upaya telah dilakukan pemerintah dalam memerangi virus corona. Beberapa ketentuan yang menjadi bagian dalam protokol kesehatan antara lain: penerapan pola hidup sehat, penggunaan alat pelindung diri, dan pembatasan interaksi fisik (WHO, 2020). Secara teknis, penerapan aturan protokol kesehatan bagi masyarakat merupakan upaya yang paling rasional dan efektif untuk diterapkan.

Desa Marubun Jaya merupakan salah satu desa yang berada di Kabupaten Simalungun Provinsi Sumatera Utara yang merasakan dampak pandemi Covid-19. Adapun dampak yang dialami adalah perekonomian yang tidak baik di Marubun Jaya, seperti Pemutusan Hubungan Kerja (PHK) bagi karyawan, berkurangnya pendapatan Usaha Mikro Kecil Menengah (UMKM) yang berpenghasilan tidak tetap dan harian, serta perubahan dalam berinteraksi dan bersosialisasi (masyarakat kini menghindari jabat tangan, cipika cipiki atau mencium pipi kanan dan kiri, berpelukan, bahkan untuk berbicarapun mereka menjaga jarak minimal satu meter). Hal ini diluar kebiasaan masyarakat dalam bersosialisasi dan menjalin keakraban jika sebelum adanya virus corona, masyarakat begitu mudahnya saling bersentuhan secara umum.
Berdasarkan survei pendahuluan yang dilakukan peneliti di Desa Nagori Marubun Jaya, Kecamatan Tanah Jawa, Kabupaten Simalungun, masyarakat Marubun Jaya memiliki risiko terpapar Covid-19 yang disebabkan oleh beberapa faktor seperti perilaku kebiasaan masyarakat Marubun Jaya, kondisi tempat tinggal/rumah, lingkungan rumah, dan pengetahuan Covid19 oleh penduduk Marubun Jaya. Pencegahan adalah kunci untuk menghentikan pandemi Covid-19 melalui aplikasi InaRisk.

Badan Nasional Penanggulangan Bencana (BNPB) meluncurkan aplikasi pemantau bencana InaRisk untuk penilaian tingkat resiko Covid-19 (BNPB, 2020). Aplikasi ini menggunakan hasil kajian yang dibangun bersama Kementerian/Lembaga terkait serta dukungan organisasi kebencanaan yang ada di Indonesia (Zakaria dkk, 2019). Aplikasi di telepon pintar berbasis android maupun iOS ini dapat mengetahui ancaman risiko Covid-19 sebelum, saat dan sesudah wabah. Data melalui InaRISK dapat digunakan untuk proses pencegahan.

InaRisk adalah portal kajian bencana yang menampilkan informasi ancaman bencana, kerentanan (populasi, kerugian fisik, ekonomi, dan lingkungan), kapasitas dan resiko bencana. COVID-19. Aplikasi Inarisk khususnya InaRisk Personal, penting dimiliki oleh masyarakat agar mampu mempersiapkan diri dan keluarga dalam menghadapi situasi ancaman bencana, pemerintah dapat melakukan pemantauan terhadap indeks risiko bencana secara umum termasuk Covid19. Penilaian Risiko Keluarga terkait Covid19 menggunakan Aplikasi Assesment inaRisk meliputi: pengetahuan tentang Covid-19, lingkungan rumah, kondisi tempat tinggal/rumah, perilaku/kebiasaan, rencana keluarga dan kapasitas keluarga.

Melalui aplikasi asessment InaRisk ini masyarakat dapat mengisi sejumlah pertanyaan sesuai dengan kategori yang tersedia yaitu pribadi, keluarga dan desa. Tools penilaian resiko terdiri dari tingkat resiko rendah, sedang atau tinggi. Setelah melakukan penilaian keluarga tersebut, maka akan muncul hasil dari penilaian berupa status risiko, rekomendasi mitigasi untuk keluarga, RS rujukan Covid-19 terdekat, serta rumah sakit tedekat dari lokasi pengisian dan 
juga peta sebaran responden yang bisa dilihat dari peta. Tujuan penelitian adalah mengetahui penilaian risiko keluarga terkait Covid-19 menggunakan aplikasi Assesment Keluarga InaRisk.

\section{METODE}

Penelitian ini merupakan deskriptif untuk menggambarkan penilaian risiko keluarga terkait Covid-19 menggunakan aplikasi assesment keluarga InaRisk. Populasi penelitian ini adalah seluruh kepala keluarga di Huta Marubun I Nagori Marubun Jaya Kecamatan Tanah Jawa Kabupaten Simalungun yang berjumlah $130 \mathrm{KK}$, dan jumlah sampel penelitian ini adalah 33 responden. Penentuan besar sampel yaitu apabila jumlah populasi kurang dari 100 orang, maka seluruh populasi dijadikan sampel, tetapi apabila jumlah populasi diatas 100 orang, maka diambil antara 20-25\% (Arikunto, 2010). Sampel diambil secara acak dengan cara undian/lotre. Penelitian dilaksanakan pada bulan September 2020.

Penilaian risiko menggunakan kuisioner aplikasi InaRisk yang diresmikan oleh Badan Nasional Penanggulangan Bencana, dengan dukungan dari Kementrian Energi dan Sumber Daya Mineral (ESDM), Kementerian Pekerjaan Umum dan Perumahan Rakyat (PU-Pera), dan Badan Meteorologi Klimatologi dan Geofisika (BMKG), serta lembaga lain terutama dalam penyediaan. Penilaian Risiko keluarga terkait Covid-19 menggunakan Aplikasi Assesment inaRISK meliputi: pengetahuan tentang Covid-19, lingkungan rumah, kondisi tempat tinggal/rumah, perilaku/kebiasaan, rencana keluarga dan kapasitas keluarga.

Kuesioner yang digunakan dalam penelitian memiliki 21 pertanyaan dengan pilihan ya diberi nilai 2 dan tidak diberi nilai 1, sehingga skor tertinggi 42 dan skor terendah 21. Penilaian resiko keluarga berdasarkan kategori risiko rendah, jika skor jawaban responden 35-42, risiko sedang jika skor jawaban responden 28-34 dan risiko tinggi jika skor jawaban responden 21-27. Penelitian dilaksanakan sesudah izin penelitian diberikan oleh Prodi Ners Fakultas Farmasi \& Ilmu Kesehatan dan Komite Etik Universitas Sari Mutiara Indonesia dengan No. 466/F/KEP/USM/X/2020. Data dianalisis univariat untuk mengetahui penilaian risiko keluarga terkait Covid-19 menggunakan aplikasi digital.

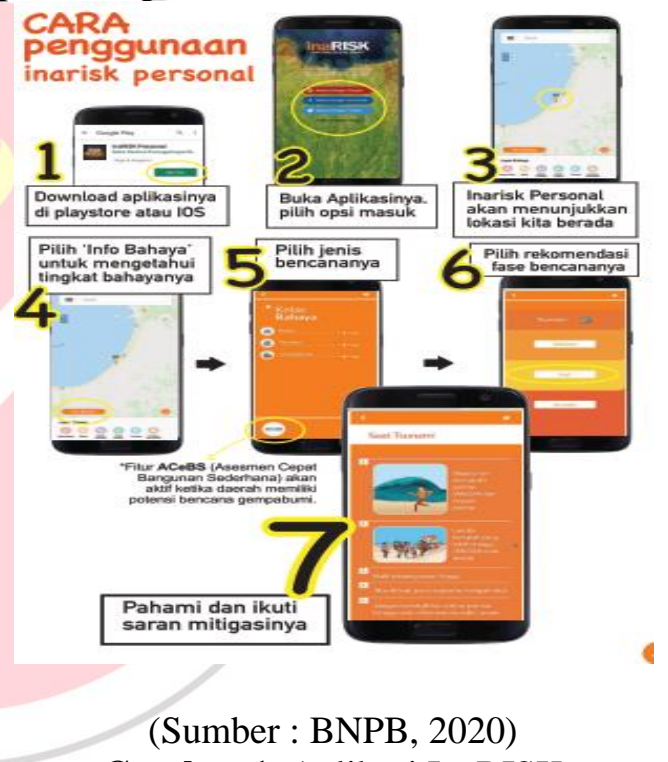

Gambar 1. Aplikasi InaRISK

Tabel 1. Daftar Pertanyaan InaRisk

\begin{tabular}{|c|c|c|c|}
\hline \multirow[t]{2}{*}{ No } & \multirow[t]{2}{*}{ Item } & \multicolumn{2}{|c|}{ Penilaian } \\
\hline & & $\mathbf{Y a}=\mathbf{2}$ & Tidak $=1$ \\
\hline \multicolumn{4}{|c|}{ Pengetahuan tentang Covid-19 } \\
\hline 1. & Keluarga mengetahui tentang Covid-19 & Ya & Tidak \\
\hline 2. & Keluarga mengetahui penyebab Covid- 19 & Ya & Tidak \\
\hline 3. & Keluarga mengetahui dampak Covid-19 & Ya & Tidak \\
\hline 4. & Keluarga mengetahui bagaimana penyebaran Covid-19 & Ya & Tidak \\
\hline \multicolumn{4}{|c|}{ Lingkungan Rumah } \\
\hline 1. & Keluarga saya tinggal di kawasan tidak padat & Ya & Tidak \\
\hline 2. & $\begin{array}{l}\text { Keluarga saya tinggal jauh dari fasilitas umum (seperti pasar, terminal, } \\
\text { stasiun, tempat ibadah) }\end{array}$ & Ya & Tidak \\
\hline 3. & $\begin{array}{l}\text { Keluarga saya tinggal di rumah dengan pencahayaan sinar matahari } \\
\text { langsung }\end{array}$ & Ya & Tidak \\
\hline \multicolumn{4}{|c|}{ Kondisi Tempat tinggal (Rumah) } \\
\hline 1. & Tempat tinggal keluarga saya memiliki sumber air bersih & Ya & Tidak \\
\hline
\end{tabular}




\begin{tabular}{|c|c|c|c|}
\hline 2. & Tempat tinggal keluarga saya memiliki MCK & $\mathrm{Ya}$ & Tidak \\
\hline 3. & Setiap anggota keluarga memiliki kamar sendiri & $\mathrm{Ya}$ & Tidak \\
\hline \multicolumn{4}{|c|}{ Perilaku/ Kebiasaan } \\
\hline 1. & $\begin{array}{l}\text { Anggota keluarga memakai masker pada saat berkumpul dengan orang } \\
\text { lain }\end{array}$ & $\mathrm{Ya}$ & Tidak \\
\hline 2. & $\begin{array}{l}\text { Anggota keluarga menjaga jarak 1,5 meter dengan orang lain ketika } \\
\text { belanja, bekerja, ibadah }\end{array}$ & $\mathrm{Ya}$ & Tidak \\
\hline 3. & $\begin{array}{l}\text { Keluarga saya memasang hand sanitizer/sabun cuci tangan di depan } \\
\text { pintu masuk untuk bersihkan tangan sebelum pegang gagang (handle) } \\
\text { pintu masuk rumah }\end{array}$ & $\mathrm{Ya}$ & Tidak \\
\hline 4. & $\begin{array}{l}\text { Keluarga saya menyediakan : tissue basah/antiseptik, masker, sabun } \\
\text { antiseptik dan desinfektan bagi keluarga di rumah }\end{array}$ & $\mathrm{Ya}$ & Tidak \\
\hline \multicolumn{4}{|c|}{ Rencana Keluarga } \\
\hline 1. & Apakah keluarga mengurangi akvitas di luar rumah & $\mathrm{Ya}$ & Tidak \\
\hline 2. & $\begin{array}{l}\text { Keluarga saya memiliki aturan dan kesepakatan dalam menerapkan pola } \\
\text { hidup bersih dan sehat (PHBS) di rumah }\end{array}$ & $\mathrm{Ya}$ & Tidak \\
\hline 3. & $\begin{array}{l}\text { Keluarga saya memiliki daftar nomor telepon penting (Polisi, rumah } \\
\text { sakit, Ketua RT/RW) }\end{array}$ & $\mathrm{Ya}$ & Tidak \\
\hline \multicolumn{4}{|c|}{ Kapasitas Keluarga } \\
\hline 1. & Keluarga saya tidak bergantung pada penghasilan harian & $\mathrm{Ya}$ & Tidak \\
\hline 2. & $\begin{array}{l}\text { Anggota keluarga tidak ada yang masuk dalam kelompok rentan (di } \\
\text { bawah } 5 \text { tahun atau diatas } 65 \text { tahun) }\end{array}$ & $\mathrm{Ya}$ & Tidak \\
\hline 3. & $\begin{array}{l}\text { Anggota keluarga tidak ada yang mempunyai penyakit } \\
\text { :jantung/diabetes/gangguan pernafasan kronik }\end{array}$ & Ya & Tidak \\
\hline 4. & $\begin{array}{l}\text { Keluarga saya sudah menyediakan perlengkapan P3K, obat-obatan dan } \\
\text { vitamin }\end{array}$ & $\mathrm{Ya}$ & Tidak \\
\hline
\end{tabular}

Tabel 2. Distribusi Frekuensi Karakteristik Responden ( $n=33)$

\begin{tabular}{lcc}
\hline Variabel & Jumlah & Persentase \\
\hline Usia & & \\
\hline 30 tahun & 0 & 0 \\
\hline $30-40$ tahun & 2 & 6,1 \\
\hline$>40$ tahun & 31 & 93,9 \\
\hline Jenis Kelamin & & \\
\hline Laki-laki & 30 & 90,9 \\
\hline Perempuan & 3 & 9,1 \\
\hline Pekerjaan & & \\
\hline Bertani & 7 & 21,2 \\
\hline Buruh & 10 & 30,3 \\
\hline PNS & 2 & 6,1 \\
\hline Wiraswasta & 14 & 42,4 \\
\hline Jumlah Anggota Keluarga & \\
\hline$<2$ & 3 & 9,0 \\
\hline $3-4$ & 15 & 45,5 \\
\hline$>4$ & 15 & 45,5 \\
\hline \multicolumn{3}{c}{ Berdasarkan }
\end{tabular}

Berdasarkan tabel 2, mayoritas usia responden di atas 40 tahun sebanyak 31 orang $(93,9 \%)$, mayoritas laki-laki sebanyak 30 orang $(90,9 \%)$, mayoritas pekerjaan wiraswasta sebanyak 14 orang $(42,4 \%)$ dan mayoritas jumlah anggota keluarga 3-4 sebanyak $15(45,5 \%)$.
Tabel 3. Distribusi Frekuensi Penilaian Risiko Keluarga $(n=33)$

\begin{tabular}{|c|c|c|}
\hline $\begin{array}{l}\text { Penilaian } \\
\text { Keluarga }\end{array}$ & Jumlah & Persentase \\
\hline Risiko Tinggi & 0 & 0 \\
\hline Risiko Sedang & 19 & 7,6 \\
\hline Risiko Rendah & 14 & 2,4 \\
\hline
\end{tabular}

\section{HASIL DAN PEMBAHASAN}

Pengukuran penilaian risiko menggunakan kuesioner inaRisk dimana ada 21 pertanyaan dengan pilihan jawaban ya diberi nilai 2 dan tidak diberi nilai 1 . Penilaian risiko keluarga terdiri dari kategori risiko rendah jika skor jawaban responden 35-42, risiko sedang jika skor jawaban responden 28-34 dan risiko tinggi jika skor jawaban responden 21-27. Berdasarkan total sampel yang digunakan, terdapat 14 kepala keluarga memiliki risiko rendah, 19 kepala keluarga risiko sedang dan tidak ada satupun kepala keluarga memiliki risiko tinggi.

Besar persentase penilaian risiko keluarga dalam kategori risiko sedang adalah $57,6 \%$ sedangkan kategori risiko rendah adalah $42,4 \%$. Hal ini menunjukan bahwa 
mayoritas keluarga di Huta Marubun I termasuk dalam risiko sedang yang persentasenya lebih tinggi dibandingkan kategori risiko rendah dan tidak satupun kepala keluarga yang termasuk dalam kategori risiko tinggi. Hal yang dinilai dalam kuisioner adalah pengetahuan tentang Covid19, lingkungan rumah, kondisi tempat tinggal/rumah, perilaku/kebiasaan, rencana keluarga dan kapasitas keluarga.

Status penilaian risiko keluarga untuk pengetahuan tentang Covid-19 di Huta Marubun I adalah baik, dimana persentase pengetahuan keluarga tentang Covid-19 sebesar 92,04\%. Hal ini menunjukan bahwa keluarga Huta Marubun I mengetahui tentang Covid-19, penyebab Covid-19, dampak Covid-19 dan bagaimana mencegah penyebaran Covid-19.

Status penilaian risiko keluarga akan kondisi lingkungan rumah di Huta Marubun I adalah baik, dimana persentasenya sebesar $88,88 \%$. Kondisi rumah tidak padat penduduk, jauh dengan fasilitas umum dan tinggal dengan pencahayaan sinar matahari langsung. Menurut Pedoman Pencegahan dan Pengendalian Coronavirus Disease Tahun 2019 dalam melawan Covid-19, bahwa perlunya membersihkan dan memberikan desinfektan secara berkala pada benda-benda yang sering disentuh dan pada permukaan rumah dan perabot. Status penilaian risiko keluarga akan kondisi tempat tinggal di Huta Marubun I adalah baik, dimana persentase sebesar 95,45\%. Keluarga masyarakat Huta Marubun I sudah memiliki sumber air bersih, sudah memiliki kamar mandi dan sudah memiliki kamar sendiri. Menurut WHO Tahun 2020, penyediaan air bersih, sanitasi dan kondisi higienis sangat penting untuk melindungi kesehatan manusia selama semua wabah penyakit menular, termasuk saat wabah Covid-19. Pengelolaan limbah yang baik dan diterapkan secara konsisten di komunitas, rumah, sekolah, pasar, penjara dan fasilitas perawatan kesehatan akan semakin membantu mencegah penularan virus Covid-19 dari manusia ke manusia.

Status penilaian risiko keluarga akan penilaian perilaku dan kebiasaan di Huta Marubun I adalah cukup baik, dimana persentasenya sebesar 75\%. Keluarga masyarakat Huta Marubun I sudah memakai masker pada saat berkumpul dengan orang lain dan menjaga jarak 1,5 meter dengan orang lain ketika belanja, bekerja dan belajar dan beribadah. Masih ada sekitar 25\% yang perilaku dan kebiasaan tidak baik. Salah satunya adalah tidak selalu memakai hand sanitizer/sabun cuci tangan di depan pintu rumah kurangnya perhatian untuk menyediakan tissue basah/antiseptik dan disenfektan dirumah. Menurut Buku Pedoman Pencegahan dan Pengendalian Coronavirus Disease Menurut Centers For Disease Control and Prevention (CDC) tahun 2020, bahwa perlunya memantau kesehatan setiap hari serta mewaspadai gejalanya. Waspadai demam, batuk, sesak napas, atau gejala Covid-19 lainnya. Terutama penting jika menjalankan tugas penting, pergi ke -kantor atau tempat kerja, dan dalam lingkungan di mana mungkin sulit untuk menjaga jarak fisik sejauh 6 kaki (Kementerian Kesehatan Republik Indonesia, 2020).

Status penilaian risiko keluarga akan Rencana keluarga di Huta Marubun I adalah baik, dimana persentasenya sebesar $80,80 \%$. Anggota keluarga sudah mengurangi aktivitas di luar rumah dan sebagian kepala keluarga memiliki aturan dan kesepakatan dalam menerapkan pola hidup bersih dan sehat (PHBS) di rumah walaupun sekitar 19,20\% secara keseluruhan rencana kurang baik dimana rata-rata keluarga tidak memiliki daftar nomor telepon penting (Polisi, Rumah Sakit, Ketua RT/RW).

Status penilaian risiko keluarga akan kapasitas keluarga di Huta Marubun I adalah baik, dimana persentasenya sebesar $80,30 \%$. Keluarga masyarakat Huta Marubun I ada beberapa yang memiliki perlengkapan P3K, obat-obatan dan vitamin. Menurut Pedoman Pencegahan dan Pengendalian Corona Virus Disease Tahun 2019 dalam melawan Covid19, menjaga sistem imunitas diri merupakan hal yang penting, terutama untuk mengendalikan penyakit penyerta. Terdapat beberapa hal yang dapat meningkatan imunitas diri pada orang yang terpapar Covid-19, yaitu konsumsi gizi seimbang, aktifitas fisik/senam ringan, istirahat cukup, suplemen vitamin, tidak merokok, mengendalikan komorbid (misal diabetes mellitus, hipertensi, kanker) (Kementerian Kesehatan Republik Indonesia, 2020). 
Sekitar 57,6\% Keluarga Huta Marubun I termasuk dalam kategori risiko sedang, oleh karena itu hal yang perlu direkomendasikan adalah sebagai berikut: cari tahu dan pelajari tentang Covid 19, sebaiknya tinggal di rumah dan membatasi aktivitas di luar rumah, berjemur diluar rumah minimal 15 menit per hari dengan menjaga jarak 1,5 meter dengan orang lain, menyediakan Mandi Cuci Kakus (MCK) keluarga, menggunakan masker pada saat berkumpul dengan orang lain, tetaplah jaga jarak anda minimal 1,5 meter dengan orang lain, buat aturan dan kesepakatan di rumah untuk menerapkan pola hidup bersih dan sehat, meningkatkan daya tahan tubuh dan rutin minum obat-obatan yang diresepkan dokter jika memliki penyakit jantung/diabetes/gangguan pernafasan kronik (InaRISK, 2019).

Jumlah keluarga yang termasuk dalam kategori risiko rendah adalah 42,4\%. Walaupun hal ini baik, tetapi keluarga tetap memiliki risiko terpapar Covid-19 oleh karena itu sebaiknya tinggal di rumah dan membatasi aktivitas di luar rumah serta buat daftar kontak penting seperti nomor telpon polisi, rumah sakit, ketua RT/RW (InaRISK, 2019).

\section{KESIMPULAN}

Berdasarkan hasil penelitian, maka dapat disimpulkan bahwa dari 33 kepala keluarga, terdapat 14 kepala keluarga memiliki risiko rendah, 19 kepala keluarga risiko sedang dan tidak ada satupun kepala keluarga memiliki risiko tinggi.

Disarankan kepada Kepala Keluarga di Huta Marubun I tetap melakukan protokol kesehatan, walaupun masuk dalam kategori risiko rendah. Sesuai dengan aplikasi InaRisk, kategori risiko rendah direkomendasikan sebaiknya tinggal dirumah dan membatasi aktivitas di luar rumah serta membuat daftar kontak penting seperti nomor telepon polisi, rumah sakit dan ketua RT/RW. Disarankan agar melakukan penelitian selanjutnya dengan kategori yang berbeda seperti penilaian risiko personal atau penilaian risiko desa menggunakan aplikasi InaRisk.

\section{REFERENCES}

Arikunto, S. 2010. Prosedur penelitian: Suatu Pendekatan Praktik. Edisi Revisi. Jakarta: Rineka Cipta.

BNPB.

http://inarisk.bnpb.go.id/panduan_singka t_ina.pdf. Diakses 11 Oktober 2020.

Berawi, M. A. 2020. Empowering healthcare, economic, and social resilience during global pandemic COVID-19. International Journal of Technology, 11(3), 436-439. https://doi.org/10.14716/ijtech.v11i3.420 $\underline{0}$.

InaRISK. 2019. Pedoman Penggunaan inaRISK. Pusat Data, Informasi Dan Humas Badan Nasional Penanggulangan Bencana.

Irawan, D., Triana, N., Suwarni, L., \& Selviana, S. 2020. Edukasi protokol kesehatan dan strategi pemasaran online melalui program kemitraan masyarakat di era pandemi COVID-19. Jurnal Masyarakat Mandiri, 4(4), 655-662.

Kementerian Kesehatan Republik Indonesia. 2020. Pedoman pencegahan dan pengendalian coronavirus disease (COVID-19).

https://covid19.go.id/p/protokol/pedoma n-pencegahan-dan-pengendaliancoronavirus-disease-covid-19-revisi-ke5. Diakses pada tanggal 20 Desember 2020.

WHO. 2020. Pertimbangan penyesuaian langkah-langkah kesehatan masyarakat dan sosial dalam konteks COVID-19. https://www.who.int/docs/defaultsource/searo/indonesia/covid19/who2019-ncov-adjusting-ph-measures-20201-eng-indonesian.

pdf?sfvrsn $=63 \mathrm{~d} 5 \mathrm{~d} 4 \mathrm{fe} \_2 . \quad$ Diakses 20 November 2020.

Zakaria, Z. 2019. Pembelajaran Untuk Masyarakat Mengenai Kebencanaan Geologi Melalui Konsep Modifikasi Pra (Participatiory Dharmakarya, 8 (3), 200-205. 